\title{
MEMORIAL
}

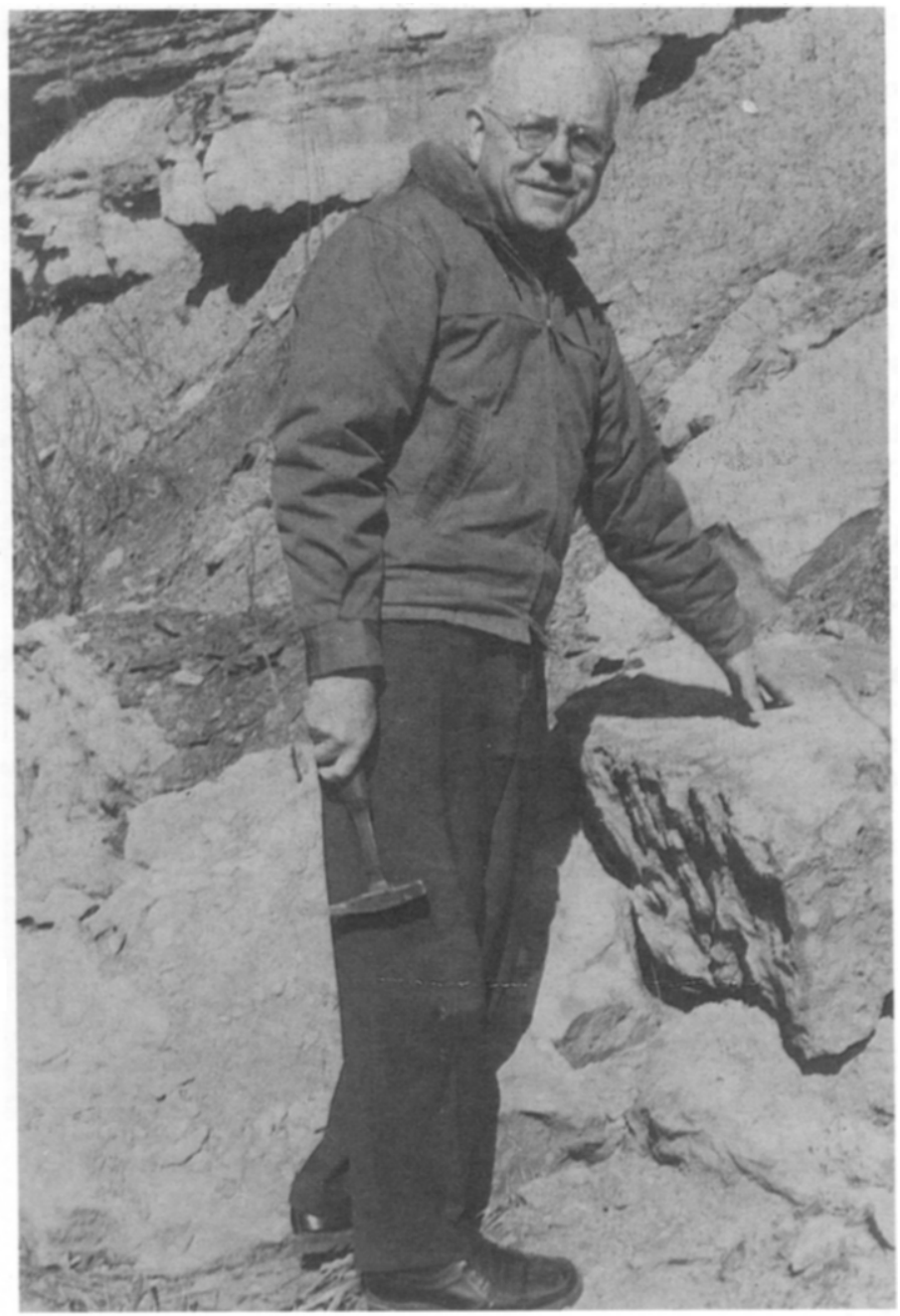

\section{CURT TEICHERT}

\author{
May 8, 1905-May 10, 1996
}

On May 1996, two days after his 91 st birthday, Curt Teichert succumbed to natural causes associated with advanced age. Curt is survived by his sister Gertrude Walker and nephew Irwin Walker of Hamilton, Ontario, and his longtime friend and confidante, Margrit Faggart of Arlington, Virginia.

Curt was born in Konigsberg, East Prussia (now Kaliningrad, Russia) on May 8, 1905. Konigsberg was the site of his primary, secondary, and university education except as an exchange student at the University of Munich and the University of Freiburg. He completed all requirements for the Ph.D. at the University of Konigsberg except publication of the dissertation in 1927, shortly after turning 22 . The degree was officially awarded in August, 1928. Two events occurred during his pre-university education that would forever shape his view of science. The first was reading Alfred Wegener's book, Die Entstehung der Kon- tinents und Ozeane, and the second was the many excursions into the Pleistocene glacial terrane surrounding Konigsberg. Wegener's book turned Curt toward geology and gave him a global view of geology at an early age. The excursions brought him into contact with the many erratic boulders of Ordovician and Silurian age derived from Paleozoic units of the Baltic region. Most boulders contained nautiloid cephalopods and the mechanical abrasion had exposed the internal structure of nautiloids belonging to a variety of different groups. Illustrations of these structures for science projects eventually led Curt to recognize the variety of internal structures and their relationship ship to other taxonomic features.

Curt met Gertrude Kaufmann in 1925, the daughter of a physics professor. Later they would marry and Trude became Curt's field companion, traveling partner, confidante, photog- 
rapher, illustrator, and mother to many students on many continents.

In 1930-31 Curt visited the United States on a Rockefeller Foundation fellowship. During this trip he was introduced to the geology of North America and August Foerste who introduced Curt to the rich cephalopod faunas of the North American Paleozoic.

Curt accepted a position on a Danish expedition to east Greenland in 1931 and would spend 15 months in Greenland, including a winter-over. His work during this period laid the foundation for later studies in Precambrian and Permian series in the region.

With the political situation in Germany in 1933 worsening, and Trude's Jewish ancestry, the Teicherts were forced to consider emigrating. Curt sold his microscope to fund passage to the United States to attend the 1933 IGC in Washington. With contacts made at the IGC and promises of support from the leader of the Greenland expedition, the Teicherts moved to Copenhagen. When the promised support never fully materialized, they were supported for the most part by Trude's translations of German scientific articles into Danish.

As conditions in Germany deteriorated, the Rockefeller Foundation funded a program to resettle German scientists, and in 1937 the Teicherts emigrated to Perth (Western Australia) to take a position in the Geology Department of the University of Western Australia. By this time Curt had published the first 50 of his 350 publications, including the benchmark study and illustration of the internal workings of the actinoceroid siphuncle, which led to understanding of the role of buoyancy regulation in nautiloid cephalopods.

Australia and Australians were always special to Curt and Trude. The geology of Western Australia was virtually unknown in 1937, and Curt found himself one of only six full-time professional paleontologists in Australia, with five on the east coast. The result was some 80 papers on Ordovician, Devonian, Permian, Jurassic, Cretaceous, and Eocene fossils and their biostratigraphic significance, and on aeolianites, algal structures in salt lakes, eustasy, palaeoclimatology, neotectonics, and on contemporary and Pleistocene reefs. His field localities, and section descriptions, in the Perth, Carnarvon, Bonaparte, and Canning Basins are still in use. Applying his knowledge of ammonoids used in zonation of the European Devonian, Curt was able to establish the biostratigraphic framework for understanding the now-famed Devonian reef system of the Canning Basin, discovering the first Australian Famennian goniatites and later the first clymeniids. In honor of his many contributions to the geology of Western Australia, a group of hills (exhumed reef core) within the reef tract at Bugle Gap near Fitzroy Crossing (Western Australia) bear the official name of Teichert Hills.

With the outbreak of World War II, Curt's travel was restricted due to his official status as a German national. He spent much of the early war years collaborating on a text book that was used for the next 40 years, writing up the results of field work, and serving as geologist on various government projects, such as mapping phosphate deposits. Along the way he began publishing on deposits of ichthyosaur and plesiosaur remains discovered in the course of work on phosphate deposits and resulting in the discovery of the youngest Australian ichthyosaur. In 1944, Curt was allowed to join Rhodes Fairbridge in Queensland to study the system of reefs now referred to as the Great Barrier Reef. Curt and Fairbridge accepted the assignment of attempting a photointerpretation of the reef system for scientific purposes and as a photographic record of the system they feared would be destroyed during an invasion. Although resources were limited, they managed to arrange for a light observation plane to fly them over the reef in a crisscross pattern while they took turns hanging out the door of the plane operating the camera. Curt's German accent understandably caused concern on the various military installations they encountered, and he was convinced to put on a basic uniform and to masquerade as a Dane. When challenged at one installation and asked by an Australian officer why a Dane would be interested in reefsCurt replied, "Because we have none!"

In 1944, The Teicherts became naturalized Australian citizens and the University of Western Australia awarded Curt the D.Sc. Unfortunately the University failed to give him tenure, offering only a 3-year contact at a much reduced salary. Curt relocated to Victoria as Deputy-Director of the Geological Survey of Victoria where he began and completed mapping of the important Buchan District with its globally important Early Devonian sequence, leading to publication on some of the earliest ammonoids.

A vacancy at the University of Melbourne brought yet another move, and Curt began his long association with the Bureau of Mineral Resources. During this time Curt served as one of the four authors of the Australian Code of Stratigraphic Nomenclature, one of eleven founders of the Geological Society of Australia, and secretary of the Committee on Correlation of the Karoo Series, later the Gondwana Congress. While at Melbourne he was awarded the David Symne Prize.

In 1949, Raymond Moore invited Curt to organize the nautiloid volume of the Treatise on Invertebrate Paleontology. Sensing that advancement within the post-war Australian system would be slow, Curt accepted a position at the New Mexico Institute of Mining and Technology at Socorro and left Australia at the end of 1952. Thus began Curt's long time association with Rousseau Flower. In 1954, Curt accepted a position with the U.S. Geological Survey in Denver where he headed the petroleum geology lab. In 1961-64 he was placed in charge of the USGS' interests/activities in Pakistan, the result being his study of the Permo-Triassic boundary in the Salt Range. He extended his activities in the region and from 1964-1976 coordinated correlation programs including those of Iran and Turkey.

In 1964, the University of Kansas offered Curt a distinguished professorship where he joined Raymond Moore in work on the Treatise and was responsible for revisions of existing volumes. In the late 1960's Curt returned to Greenland with Bernard Kummel to continue work on the Permo-Triassic boundary. In 1971, he was elected president of the Paleontological Society. Curt was forced to retire from teaching in 1975 by the then policy of retirement at 70 .

In 1977 and with the urging of David Raup, the University of Rochester (Rochester, NY) offered Curt a lifetime appointment as Adjunct Professor with full privileges. Curt rewarded Rochester with NSF funding and a final 60 or so papers and reviews including major works on the Permo-Triassic boundary in east Greenland, and on Chinese Cambrian and Ordovician nautiloids. He received the Raymond Cecil Moore Medal in 1982 and Paleontological Society Medal in 1984.

Curt was blessed with two special individuals in Rochester: Carlton Brett who understood and appreciated Curt's unique blend of geology; and Margrit Faggart, who acted first as Curt's secretary, then invaluable assistant, and finally as the Teichert's friend, confidante, and companion. Carlton organized the 19881989 Curt Teichert-Festschrift volume (Struve, 1988) containing contributions from 40 friends and former students.

In November, 1993, Trude's sudden passing ended 66 years of marriage and companionship, and Curt's life was never again the same. His final move in early 1995 to Arlington, Virginia, brought him closer to friends in the Smithsonian and the USGS.

Curt produced more than 350 reviewed publications. His first 
in 1926 were on geophysics and volcanology but by 1929 he has shifted to biostratigraphy and paleontology (nautiloids). Generally producing 5 refereed articles a year, he produced more than 12 in 1947 and 1948 and again after official retirement in 1976 and 1993. At the time of his death he was actively collaborating on the development of a database of all valid Paleozoic nautiloid species together with stratigraphic and geographic information. The data base will be published with the revision of Part K (the nautiloid volume) of the Treatise.

Curt's reputation as a scientist and paleontologist extended far outside his speciality of nautiloid cephalopods. By the time of his death, 40 species (only 16 of which are cephalopods), 5 genera and 1 family have been named in his honor using either his first or last name.

Curt always considered students to be his greatest legacy. In his view there was no such thing as "former" students and class was never over. Most of us privileged to have been touched by his greatness and nurtured in his counsel continued the asso- ciation throughout Curt's life. We not only lost a great scientist and teacher but a friend as well.

\section{REFERENCE CITED}

Brett, C. E., Struve, W., AND Yochelson, E. L., 1988, Curt TeichertFestschrift: Senckenbergiana Lethaea, v. 69: Frankfurt am Main, Senckenbergische Naturforschende Gesellschaft, 628 p.

Rex E. Crick

Department of Geology

University of Texas at Arlington

Arlington, TX 76019-0049

George D. Stanley, Jr.

Department of Geology

University of Montana

Missoula, MT 59812 